Relations industrielles

Industrial Relations

\title{
Using the Social Sciences, by Albert Cherns, London, Routledge and Kegan Paul, 1979, 502 pp.
}

\section{Alexander J. Matejko}

Volume 34, numéro 3, 1979

URI : https://id.erudit.org/iderudit/029001ar

DOI : https://doi.org/10.7202/029001ar

Aller au sommaire du numéro

Éditeur(s)

Département des relations industrielles de l'Université Laval

ISSN

0034-379X (imprimé)

1703-8138 (numérique)

Découvrir la revue

Citer ce compte rendu

Matejko, A. J. (1979). Compte rendu de [Using the Social Sciences, by Albert

Cherns, London, Routledge and Kegan Paul, 1979, 502 pp.] Relations

industrielles / Industrial Relations, 34(3), 623-626.

https://doi.org/10.7202/029001ar

Tous droits réservés (C) Département des relations industrielles de l'Université Laval, 1979
Ce document est protégé par la loi sur le droit d'auteur. L'utilisation des services d'Érudit (y compris la reproduction) est assujettie à sa politique d'utilisation que vous pouvez consulter en ligne.

https://apropos.erudit.org/fr/usagers/politique-dutilisation/ 
the administration of contemporary collective bargaining legislation. At a time when trade unions are complaining that labour boards are too legalistic and formal, it is surprising to see the argument made for a return to the more formal procedure of a court. The author, moreover, appears to underestimate the importance of the representative members from labour and management in the decisionmaking of the labour boards. The board members, who bring to the Board extensive labour relations experience, do have a significant influence on labour board decisions an influence that would not be present in a labour court. The author, however, does recognize this problem, proposing that administrative matters be left to a tri-partite board that might be advisory to the court, which would deal with more fundamental matters. Such a structure, though, would be far too cumbersome to process cases with the expedition required in labour relations. One can only conclude that the author does not recognize the lesson of the first Labour Court - that a purely judicial structure is not well suited for the administration of labour relations laws.

Don CARTER

Queen's University

L'indexation des salaires dans les pays industrialisés à économie de marché, Genève, Bureau international du travail, 1978, $67 \mathrm{pp}$.

Cette monographie publiée par le Bureau international du travail comprend trois parties. Le premier chapitre traite des modalités techniques de l'indexation des salaires à un indice du coût de la vie. Les chapitres II à $\mathrm{V}$ décrivent la situation des différents pays industrialisés selon que l'indexation est généralisée, limitée, presqu'inexistante ou qu'elle constitue un élément d'une politique publique de revenus. Enfin, un dernier chapitre présente une synthèse des attitudes patronales, syndicales et gouvernementales face à l'indexation des salaires dans les pays étudiés.
Au chapitre I, après une brève discussion des notions de rémunération et de coût de la vie, on trouve un examen assez complet des méthodes d'indexation des salaires: variable à ajuster, périodicité des ajustements, indice utilisé, période de référence, forme et montant d'ajustement. Il est un problème assez aigu qui n'est pas mentionné, celui de l'intégration de l'indemnité de vie chère au salaire régulier.

Les chapitres suivants contiennent des renseignements intéressants mais assez généraux sur l'utilisation de l'indexation des salaires au coût de la vie dans les conventions collectives de plusieurs pays. La catégorisation des expériences nationales est révélatrice de l'influence exercée par certains facteurs sur le phénomène de l'indexation: le contexte historique, le degré de centralisation de la négociation, le degré d'intervention étatique dans la distribution des revenus, la maturité du régime de relations de travail, etc... Bien que le document s'en tienne au niveau descriptif, de nombreuses hypothèses de recherche sautent aux yeux du lecteur attentif et intéressé à la théorie des sytèmes de relations industrielles.

Bref, il s'agit d'une brochure utile, qui devrait intéresser surtout le profane en la matière, désireux de se renseigner sur le phénomène de l'indexation des salaires au coût de la vie au plan international.

Claude RONDEAU

Unịversité Laval

Using the Social Sciences, by Albert Cherns, London, Routledge and Kegan Paul, 1979, $502 \mathrm{pp}$.

Social sciences may contribute to policy making by providing practitioners with basic concepts and theories about man and society, delivering data and devising technical solutions to problems. According to Cherns, "by increasing the policy-maker's knowledge and understanding of the system in which he is operating and the characteristics and poten- 
tialities of its human components, social science knowledge can clarify and increase the options available to him" (p. 145). In practice the relations existing between research institutions and users of research are full of problems depending on the nature of research (pure basic research, basic objective research, operational research, action research) and the openess of practitioners to learn from research. Options available to decision-makers become much clearer and reliable when they are formulated on the basis of research. On the other hand, even the best research will not help much if the client system does not have adequate channels for diffusion of valid knowledge. Very often by changing mutual perceptions of policymakers and social scientists it is possible to improve the research application. The utilizing organization and the research team operate usually on different time scales; the learning ability of the utilizing organization is quite often very limited; research application fails when the mutual interdependence between various parts and power levels of the organization are not taken into consideration; practitioners still only rarely are able and willing to carefully select research projects actually needed by them at various stages of decision making (there is a general lack of knowledge and even imagination in this respect).

The book by $A$. Cherns under review here should be very useful for all people who directly or indirectly are related to social science policy, organization of social research and its practical utilization in industry, big corporations, developing countries, the military, etc. The book consists of these elements and is based on various papers written by the author during the period of several years. His past experience in the Social Science Research Council in the UK as well as his contemporary world-wide activity in the fields of sociotechnics and the quality of working life movement, in addition to his professorship (since 1966) at Loughborough University, make him a particularly valuable contributor.
In the first part of the book readers will find a careful analysis of basic problems of social science policy, clarification of concepts, as well as the presentation of social science development and utilization in various countries, particularly in the UK. The second part is devoted to the contribution of social sciences to industry, complex organizations, the quality of working life, science and technology policy, and the armed services. Here we can find some valuable contributions to the field of industrial relations.

One of the most important contributions is the formulation by $\mathrm{A}$. Cherns of the ten principles of sociotechnical design based on the understanding that "organizational objectives are best met by the joint optimization of technical and the social aspects, exploiting the adaptability and innovativeness of people in attaining goals, instead of overdetermining technically the manner in which these goals should be attained" (p. 311). According to Cherns, the process of sociotechnical design must be compatible with its objectives, accordingly modified and based on the voluntary consent of people involved. No more should be specified in the sociotechnical design than is absolutely essential, and this essence should be specified very clearly. The correction of variances and deviances should be done on the spot, and not only much later. "The fewer the variances that are exported from the place where they arise, the less the levels of supervision and control required and the more 'complete' the jobs of the people concerned-to whom it now becomes possible to allocate an objective and the resources necessary to attain it"' (p. 313). Organization should be designed according to the multifunctional principle (organism versus mechanism) in order that it to be able to fulfill the whole variety of changing demands, and secure the high level of flexibility and adaptability. The boundaries drawn between various parts of the organization should not interfere with the effective functioning of the whole workplace. Information systems should be designed to provide information in the first place to the point where action on the basis of it will be needed. 
Sophisticated information systems can "supply a work team with exactly the right type and amount of feedback to enable them to learn to control the variances which occur within the scope of their spheres of responsibility and competence and to anticipate events likely to have a bearing on their performance" (p. 317). The systems of social support should be designed so as to reinforce the behaviours which the organization structure is designed to elicit. An objective of organizational design should be to provide a high quality of working life to its members. The strains of the changeover period from one model of organization to another one should be carefully taken into consideration. The whole sociotechnical design should be treated as a reiterative process; instead of looking for a perfect final solution it is much more reasonable to be open to constant improvements.

All these guides may be very useful in the field of industrial relations where the sociotechnical design becomes more and more popular. According the Cherns, "the role of the social scientist is facilitatory, providing what is needed in new ways of looking at and perceiving organizations and their environments"' (p. 319). The quality of working life movement is gaining its strength and popularity due mainly to changing social circumstances. There is a growing need to examine carefully, from a broad theoretical perspective, the basic principles on which this movement should be founded in the long run. The insight offered by Cherns represents one of the major contributions in this respect, similar in its quality to the book by $A$. Podgorecki, Practical Social Sciences, London 1975.

When dealing specifically with the quality of working life movement (QWL), Chern takes into consideration, among others, all basic criticisms based on the fears that: the main attention may be diverted from the issue of efficiency, the conflict-based nature of organizations may be neglected, the position of trade unions may be weakened, and the working people may be manipulated against their own vested interests. Cherns admits that the sociotechnical approach is least effective when attempted within a context of conflict (p. 358) and that QWL by importing a new meaning to the concept of job satisfaction does not necessarily push average satisfaction scores up (p. 359). There are several dangers to QWL leading, among others, to the encapsulation and erosion of innovations animated by the social scientists in industry, but the strength of QWL comes from the fact that it responds to the major trends and needs of the developed countries. Industrial enterprises are forced by the changing circumstances to bother much more than before about their public image. The young generation shows growing demands of personal satisfaction and growth opportunities at work. There is a general switch to the more or less sophisticated services in which personal responsibility and commitment play a major role. Management is constantly losing its traditional authoritarian basis and the power to penalize employees (this is particularly evident in Sweden).

Under such circumstances QWL has become a historical necessity. Its basic assumptions are: that organizations have a technical system which sets the parameters for the operation of its social system, consisting of patterns of interactions which are partly task-based and partly in the service of preserving the integrity of the system itself, and that the objectives of any organization allow a choice among technologies; that people have their own needs, some of which they expect to have satisfied in their work and others which may emerge, and require satisfying, in work situations. Associated with these assumptions or axioms are certain values: autonomy is preferable to dependence; high levels of skill are preferable to low; learning is good; a high degree of selfinvestment in work is good, provided that the work itself and the work situation offer opportunities for growth and self-realization ( $p$. 353).

As emphasized before, the book by $\mathrm{A}$. Cherns is a valuable contribution to the grow- 
ing literature on applied social sciences in general, and sociotechnics in particular. The only criticism which I have is that too many diverse topics have been squeezed into one book. This is a handicap typical of collections of diverse papers treated as a basis for publication. I would have preferred a book on sociotechnics written especially for this purpose and I hope that sooner or later the author will furnish us with one.

\section{Alexander J. MATEJKO}

\section{University of Alberta}

Les relations du travail: Employeurs, Personnel, Syndicats, Etat, par Dimitri Weiss, $4 \mathrm{e}$ édition actualisée et augmentée, Paris, Dunod, 1978, 348 pp.

Qu'un ouvrage à caractère scientifique et professionnel connaisse quatre éditions en quelques années est déjà un signe de sa qualité intrinsèque et de sa correspondance à un besoin.

Nous avons employé le mot "édition» en non "réimpression», car il s'agit bien d'un texte que l'auteur a chaque fois substantiellement amélioré, complété et augmenté. Cette quatrième édition de Les relations du travail en fait un ouvrage nouveau dont les usagers des éditions précédentes ne peuvent se passer. Ayant déjà eu l'occasion de se familiariser avec l'ampleur des connaissances de l'auteur et son souci d'exactitude, ils trouveront ici une grande synthèse de ce que certains désignent sous le nom de «discipline des relations du travail».

Bien que l'ouvrage s'adresse plutôt à un public français et qu'il réfère surtout à la situation qui existe en France, le cadre théorique que l'auteur adopte possède une valeur générale applicable dans tous les pays.

En vingt et un chapitres d'inégale longueur, Dimitri Weiss aborde l'essentiel des relations du travail et permet au lecteur de comprendre les points suivants: la nature des relations du travail distinctes des relations humaines; les conflits du travail et la négociation collective; les cadres dans lesquels s'inscrivent les institutions du personnel et leur rôle; les moyens d'information au niveau de l'entreprise et les approches, les fonctions et les politiques qui s'y rattachent.

Les lecteurs canadiens, qu'ils soient dans l'enseignement ou la pratique des relations du travail tant du côté syndical que du côté patronal, tireront grand profit à la lecture de cet ouvrage. À la lumière des expériences françaises analysées, ils pourront d'une part trouver des moyens d'améliorer notre régime des relations du travail. Par ailleurs, ils pourront aussi apprécier ce que nous possédons et éviter de s'orienter dans des voies qui ne les conduiront qu'à des déceptions.

Gérard DION

Université Laval 